\title{
Ölüm Bilincine Yönelik Düşünceler Bağlamında Macbeth'in Sinemadaki İzdüşümüne İlişkin Bir İnceleme
}

\author{
Melike Büyü*
}

Özet

İnsan için temel hakikat onun ölümlü olmasıdır. İnsan, diğer canlılardan farkh olarak, eylemlerini sonlu olduğunun bilinciyle gerçekleştirir. Ölüm, yaşamın bir anlamının olup olmadığı üzerine bir sorgulamayı açık hale getirir. Sonluluk insana, yaşamın bulunulan an ve zaman içinde değerli ve anlaml kılınması için bir neden vermektedir. Yaşamın bir sımırının olduğunun bilincine varıldığında, onu değerli ve anlamlı kılmak adına harekete geçme fırsatı yakalanır. Çünkü yaşam geçici ve insan ölümlü olduğuna göre, insan eylemlerini anlamlı kılmanın ve yaşamını haklı çıkarmanın bir yolunu bulmalıdır. Her gün benzer eylemleri sürdürmeye yazgllanan insan, bir gerçeklik olan ölümü göz ardı ettikçe ve ölüme meydan okumadıkça, ona öğretilen değerler, doğrular ve yasalar altında yaşamaya mahkûm olur. Edilginliğini yenemez. Ölüm göz ardı edildiği sürece, sıradan ve anlamsız eylemlerden kurtulmak zorlaşır ve insan kendini aşamaz. Bunun aksine, ölüm bilincine varıldı̆̆ında, yaşamın anlamsızlı̆̆l, acıları, mutsuzluklar veya mutlulukları olumlanarak, varoluşun bir hiçliğe değil, bir değere dönüşmesi sağlanır. Bu bağlamdan yola çıkılarak, çalışmada ölüm bilincinin önemi ve sonluluğun insanın yaşamında asıl değerli yan olduğunu ortaya koymak amaçlanmaktadır. Buradan hareketle bu çalışmada, öncelikli olarak, düşünce tarihi boyunca ölüm bilincine dair fikirler ortaya koymuş filozoflarm düşüncelerinden yararlanılmıştır. Bu düşüncelerin izinden gidilerek ilkin Shakespeare'in Macbeth tragedyası üzerinden ve sonrasinda Akira Kurosawa'nın Macbeth'in film uyarlaması üzerinden hareket edilerek ölüm bilincinin, varoluş üzerindeki önemi, detaylı bir şekilde incelenerek açıklanmaya çalışılmıştır.

Anahtar Kelimeler: Ölüm Bilinci, Macbeth, Sinema

\footnotetext{
*ORCID: 0000-0002-9040-4118

E-mail: buyumell@gmail.com

DOI: 0000-0002-9040-4118
}

Geliş Tarihi - Recieved: 15.01.2020

Kabul Tarihi - Accepted: 05.05.2020 


\title{
A Study Of Macbeth's Reflections In Cinema In The Context Consciousness Of Death
}

\author{
Melike Büyü*
}

\begin{abstract}
Death has a place in human's life as the truth which is as real and inevitable as the life itself. Since death has such an active position in human's life, by affecting all of his actions, death becomes a part of his identity. This phenomenon which is in the center point of existence opens up an questioning on whether life is worth for living or not. The passing of life and the end of man causes all actions in world to turn into absurdity. Individuals who continue to do the same acts everyday and struggle to create common meanings with others are imprisoned in this vicious circle. Albeit, after at the very time of this questioning rises a new awareness which makes it possible to seize a chance to take a step towards a meaningful life. Because to live life with the awareness of it's passing gives man a reason to present a meaning.Since life is temporal and man is mortal, a man has a chance to have meaningful actions in the time and locations of his own and to justify his life. If the opposite happens, death as a reality is ignored, people drag their existence towards nothingness for the temporal wordly materials which have no meanings. Thus they go after the ordinary and meaningless actions and they cannot justify their existence. He can only transcend himself with the consciousness of death. Thus in this article first of all the ideas of philosophers on the consciousness of death throughout intellectual history are utilized, after then through Shakespeare's Macbeth the effect of the consciousness of death on people has been studied in a detailed manner by the reflection of literary works and the pictures.
\end{abstract}

Key Words: Consciousness of Death, Macbeth, Cinema

*ORCID: 0000-0002-9040-4118

E-mail: buyumell@gmail.com

DOI: 0000-0002-9040-4118

Received - Geliş Tarihi: 15.01.2020

Accepted - Kabul Tarihi: 05.05.2020 


\section{Giriş}

İnsan, doğduğu andan itibaren ölüme doğru ilerleyen bir sürecin içine girer. Yaşamın ve ölümün böylesine iç içe olması, varoluşun ve gerçekleştirilen eylemlerin değerini sorgulamaya açık hale getirir. İnsan, yaşarken ona öğretilenlerle hayatta kalmaya çalışırken bir taraftan da yaşamın yaşanmaya değip değmeyeceği üzerine düşünceler geliştirir. Her gün benzer eylemleri gerçekleştirmek zorunda olan bireyler, bu kısır döngüyü fark ettiklerinde bir anlamsızlık ve boşluk içine girebilirler. Kişi, yaşamını ve ölümünü haklı çıkarabilmek adına, karşı karşıya kaldığı bu anlamsızlığı ve boşluğu doldurma yoluna girer. Yine de yaşamın anlamsızlığını farkında olan; acı çeken, mutsuzluk içinde kıvranan insanlar dahi ölüm karşısında geri çekilir. Aslında varoluşa dair temel problem burada ortaya çıkmaktadır. Ölüm kabul edilmediği sürece yaşamda etkin bir konuma gelmek zordur. İnsanlar, bu korkularının arkasına sığınmaya çabaladıklarında, yaşamlarını anlamsız eylemler üzerine kurgulamaya da alışmaktadırlar. Sonluluk bilincinin farkındalığına erişilmediğinde, yaşamın asıl yanları sorgulamaya kapanır ve var olanın güdümüne girmek kolay bir hal alır.

Bu bağlamda çalışmasının amacı, ölümün nihai oluşu karşısında, insanın eylemlerinin anlamsızlığa karıştığı inanışının aksine, insanın tam da bu sonluluk bilinciyle, yaşamında değerli ve kalıcı anlamlar yaratabileceğini ortaya koymaktır. Bu yüzden insanın ötelediği ve korku duyduğu ölüm korkusunun anlamsızlı̆̆ını ortaya koymak önemlidir. Dolayısıyla, çalışmanın asıl çıkış amacı, ölüme yazgılı olan insanın, kendini yaşadığı süre içinde gerçekleştirmesini sağlayacak, onu etkin bir konuma sokacak olan, ölüm bilincine varmasının önemi ortaya koymaktır. Aynı zamanda varoluşun, ölümle birlikte bir hiçliğge dönüşmekten daha fazlasının olabileceğini ortaya koyan eylemlerin altını çizmektir. Çünkü sonlu bir varlık olan insan, ancak gerçek anlamda ölümlü olduğunun bilincine vardığında, kendini gerçekleştirme imkânı bulur. Buradan hareketle, çalışmanın ilk bölümünde, Friedrich Nietzsche, Friedrich Hegel, Albert Camus gibi düşünürlerin, ölüm bilinci üzerine ortaya koydukları görüşlere yer verilecektir.

Çalışmanın İkinci Bölümü'nde, Shakespeare'in eserlerinden yararlanılacaktır. Shakespeare'in, kralları ve soyluları ele aldığı eserleri, çalışmanın ana problemini çözüme götürebilmek adına önemli bir yere sahiptir. Çünkü özellikle krallar, dünyada neredeyse tanrısal diyebileceğimiz bir güce sahiptirler. Arzu ettiklerine kavuşmaları, çoğu insana göre çok daha kolaydır. Sıradan bir insanın gerçekleştirebileceği eylemler ile bir kralın gerçekleştirebilecekleri aynı değildir. Bu yüzden Shakespeare'in kral ve soyluları ele aldığı oyunları, insan potansiyelinin sınırlarını görebilmek adına önemlidir. Bu anlamda Macbeth (Macbeth, Shakespeare, 2018) Shakespeare' in diğer tüm eserleri içerisinde, kendi sınırını en çok zorlayan, sınırına en hızlı şekilde varmaya çalışan karakterdir. Aynı zamanda karakter, aldığı ölümsüzlük kehanetiyle, sonsuz yaşam düşüncesinin, olumsuz sonuçlar doğurabileceğinin iyi bir örneğidir. Bu sebeplerden dolayı, özellikle Macbeth tragedyası üzerinde durularak, Shakespeare' in diğer tragedyalarına kısaca değinilecektir. Bu eserler ele alınırken, ilk bölümde ortaya koyulan düşünceler izlenerek, düşünürlerin ortaya koydukları fikirlerden hareketle incelemeler yapilacaktır. 
Çalışmanın son bölümününde, Birinci Bölüm'de oluşturulan kuramsal çerçeve bağlaminda ve İkinci Bölüm'de incelenen Macbeth eseri üzerinden Shakespeare'in bu tragedyasina uyarlanan Kumonosu-jō (Kanlı Taht, yön. Akira Kurosawa, 1957) filmi incelenecektir. Bu anlamda filozofların düşüncelerinin ve edebi metinlerin yanında, sinemanın ölüm hakkında neler söylendiğine ve nasıl anlatımlar ortaya koyulduğuna değinmek gerekli görülmüştür. Aynı zamanda Macbeth üzerine çekilmiş onlarca sinema filmi olduğu bilinmektedir. Fakat tüm bu filmlerin tek bir çalışma ile irdelenemeyeceği açıktır. Dolayısıyla çalışmanın Üçüncü Bölümü'nde yer alan filmin seçiminde, sinema tarihinde önemli bir yeri olan ve Batı' dan çıkmış bir eseri farklı bir coğrafyada ortaya koyan, bu anlamda evrensel bir anlatım sunan Kanlı Taht filmi uygun görülmüştür. Bu film, konumuz bağlamında çözümlemeye tabi tutulacaktır. ${ }^{1}$

\section{Düşünce Tarihinde Ölümün İrdelenme Biçimleri}

İnsan için temel hakikatlerden biri, ölecek olmasıdır. Ölüme yazgılı olduğunun bilincinde olan tek varlığın insan olduğu, düşünce tarihi boyunca da kabul görmüştür. İnsan eylemlerini, sonlu olduğunun bilinciyle gerçekleştirir. Bundan dolayı ölümün, eylemlerin temel kaynağı olduğu söylenebilir. Ölümün bir gün deneyimlenecek olması, insana yaşamak ve eyleme geçmek için motivasyon kaynağı oluşturur. Böylelikle insan, varlığını ortaya koyabilmek, kendini gerçekleştirebilmek adına dünyada bir anlam arayışına girer. Belki de insan, ölüm bilincine sahip olmasaydı; yaşam şu an ki şeklini almazdı ve insanlar yaşama aynı değeri yüklemezdi. Bununla ilgili Malpas şu sözlere değinir: "Sonlu olmayan bir yaşamın bıktırıcı bir yaşam- bitmek bilmez bir can sıkıntısı- olmasının yanı sıra bir yaşama sahip olmak, yalnızca yaşamak ile aynı şey değildir. Aslında ölebilir olmaktır" (2017: 228). Buradan hareketle denilebilir ki insan için sonluluk bilincine sahip olmak yaşamın kendisi kadar önemlidir.

Ölüm bilinci insanı, diğer canlılardan ayıran en temel özelliklerin de başında gelir. Hayvanlarda da insanlarda olduğu gibi hayatta kalma içgüdüsü vardır. Tehlike karşısında kendilerini savunmak için her şeyi yapmaya hazırdırlar. Fakat hayvanların, kendi sonluluklarına/ölümlülüklerine yönelik bir bilinçleri yoktur. Schopenhauer, bu konu hakkında fikirler otaya koymuş ve bununla ilgili şöyle söylemiştir: "Hayvanlar, ölüme dair gerçek bir bilgiye sahip olmaksızın yaşarlar. Bu yüzden de herhangi bir hayvan kendi kendisini sonsuz olarak idrak ettiği için türünün mutlak yok olmazlığı ve ölümsüzlüğünden yararlanır" (2016: 55). Bu yüzden hayvanlar, insanlardan farklı olarak içgüdüleri doğrultusunda, bir gün ölmeyecekmiş gibi yaşamaya meyillidirler. İnsanlar ise ölümün kesinliğinin farkındadır ve bu durum bir bilinci de beraberinde getirir. Bu bilinç, toplumların kültürlerini ve inanç sistemlerini farklı yönlerde etkilemiştir. Westermarck'a göre (Ökten, 2010) birçok inanışta, ölüler öldüklerini kabul etmek istemez, yaşayanları öldürmeye çalışır ya da kendileri yaşayanların dünyasına geri dönmek isterler. Bu durum insanların ölüme karşı

\footnotetext{
${ }^{1}$ Bu makale, "Ölüm Bilincine Yönelik Düşünceler Bağlamında Macbeth'in Sinemadaki İzdüşümlerine İlişkin Bir İnceleme" (Danışman: Dr. Öğr. Üyesi Çağdaş E. Çağlıyan, Başkent Üniversitesi, Ankara, 2019) adlı yüksek lisans tezimden uyarlanmıştır.
} 
olumsuz bakışının yansımalarından biridir. Genellikle insanlar, ölümle yüz yüze gelmeden onun bir gün gerçekleşeceğine inanmazlar. Başkalarının ölümü her ne kadar olağan görünse de insanın kendi ölümü ona olağandışı bir durum gibi görünür. İnsan, bir şekilde ölümlü olmayı kendine yakıştırmaz. Sonlu bir varlık olduğu düşüncesi insana acı verici görünür. $\mathrm{Bu}$ durum, bir bakıma insanın kendini ölümsüz bir varlık gibi hissetmesine neden olur.

$\mathrm{Bu}$ durum, insanın en büyük trajedilerinden biri olan ölümsüzlük arzusunun doğmasına da sebep olur. Fakat sonlu olduğunu bilincinde olan bir canlının, ölümsüzlük arayışında olması, büyük bir çıkmazın içine girmesi demektir. Bu durumun en iyi temsillerinden birine Gılgamış Destanı'nda rastlamak mümkündür (2016). Gılgamış, ölü biriyle karşılaştığında şöyle söyler: “Ben de Enkidu gibi ölmeyecek miyim? Gönlümü üzüntü kapladı. Bana ölüm korkusu geldi. (...) Ay Tanrısına yalvardım. Bu yalvarışım, bütün tanrılara yöneldi: Korkulu yerde beni sağ bırakın!" (2016: 21). Gılgamış, ölüm korkusuyla birlikte bir ölümsüzlük arayışına da girer. Bu uğurda aslanları, devleri öldürür; denizleri aşar. Akrep adamlar ile savaşır. Yeraltı dünyasına giden yolu dahi bulur. Fakat ne yaparsa yapsın ölümsüzlüğü bulamaz. Böylece Gılgamış, ölümün insanın kaçınılmaz bir gerçeği olduğunu kabullenir. Ölümden kurtulmanın bir yolu olmadığına göre onunla yaşamayı öğrenmek ve onu kabul etmek sonlu olan insan için en mantıklı yollardan biri olarak görünür.

Peki ya Gılgamış ölümü kabul etmeyip onu yenmek için çabalamaya devam etseydi ne olurdu? Muhtemelen tıpkı diğer insanlarda olacağı gibi ölümü yadsımanın birtakım sonuçlarına katlanması gerekecekti. Çünkü insanın ölümü yadsıması, kendi doğasına karşı gelmesi ve varlığının bir parçasını reddetmesi demektir. İnsanlar, her ne kadar ölümü görmezden gelme eğiliminde de olsalar ölümün bir yere gittiği veya yok olduğu söylenemez. Öyleyse insanın ölümü görmezden gelme çabası gerçek dışı bir dünyada yaşaması anlamına gelir. İnsan, bu dünyaya ne kadar tutunursa, içindeki nesnelere de bir o kadar bağımlı hale gelir. Bu bağımlılık zamanla insanın bağlı olduğu nesneler karşısında köleleşmesi demektir. Onlara bağlandıkça da özünü daha çok yitirir. Bunun sonucunda insan gitgide daha edilgin bir varlığa indirgenir. Bu konuyla bağdaştırabileceğimiz düşüncelerin izlerini Nietzsche, Hegel ve Camus'nün söylemlerinde bulabiliriz. Buradan hareketler ilkin, Nietzsche'nin düşüncelerinden yola çıkılacak ve diğer düşünürlerle birlikte konu detaylandırılacaktır.

\section{Nietzsche'de İnsanın Yaşamı ve Ölümü Haklı Kılması}

Nietzsche dünyayı salt gelip geçiciliğe indirgemez; aksine dünyadaki yaşımı hakikat olarak görür. İçinde bulunduğumuz dünya yaşamını yüceltir ve yaşamın olumlanmasının gerekliliğini savunur: “Görün! İyice görün! Budur sizin yaşamınız! Budur akrebi varoluş saatinizin!" (Nietzsche, 2016a:100). Onun için esas olan, dünyada olup bitendir; bu yüzden insanın tüm varlığını dünyada ortaya koyması gerektiğine inanır. Fakat, bunu yaparken, insanın günlük çıkarları doğrultusunda, edilgin bir şekilde yaşamasını da yadsır. İnsanın kendini güçlü bir şekilde ortaya koyabilmesi için toplum tarafından belirlenen iyi-kötü gibi ahlaksal kavramların ötesinde bulunması gerektiğini vurgular. Aksi takdirde bireyler, adeta birer gölge insanlara dönüşürler (Camus, 2011). Gölge insan ile anlatılmak istenen aslında açıtır. Nietzsche' ye göre tamamen uydurma ve yanılgılar dünyası olan öteki bir dünya için şu an içinde bulunulan "tutkular ve çı̆̆lıklar evreni" (Camus, 2011: 58) yok sayılmaya 
çalışılır. Dünya üzerindeki haz ve arzular yadsınır. Fakat bir değer yaratılacaksa tam da bulunulan dünyada, bulunulan süre içinde yaratılmalıdır. Nietzsche' ye göre insan, tanrıyı, öteki dünyayı, ahlakı yok saymadan bunu başaramaz. İnsanın bu gücü ortaya koyabilmesi etkin bir birey olması adına son derece önemli görünür. Bunu ortaya çıkarmamak insanın alıştığı düzenin kölesi olmasının sonuçlarından biridir. Nietzsche bununla ilgili şuna değinir: "İşte senin bağışlanmaz yanın. Bütün güçler kendi elinde ama imzanı atmaya yanaşmıyorsun" (akt: Camus, 2011: 65). Sıklıkla Hristiyanlık eleştirilerine yapan Nietzsche, sonsuz yaşam kavramının, yaşamı olumsuzlamaya sebep olduğuna inanır: "Dünyadan nefret etme, duygulanımları lanetleme, güzellikten ve tensellikten duyulan korku, bu dünyaya daha iyi kara çalmak için uydurulmuş bir öbür dünya, aslında hiçliğe, sona, kalıbı dinlendirmeye yöneliktir" (Nietzsche, 2016: 12). İnsanlar öte dünyada daha iyi bir yaşama sahip olabilmek adına içinde bulundukları şu ana sırtlarını dönerler. Bu da zamanla insanın, doğal benliğini kaybetmesine neden olabilir. İnsanlar, öteki dünya için yaşamdaki neşeyi, mutluluğu, hüznü ve hatta mutsuzlukları kaçırırlar. Nietzsche, yaşamın nasıl değerli kıllanabileceği üzerinde düşünceler ortaya koyarken Antik Yunan'dan etkilenir. Antik Yunan'a dönüp bakıldığında, insanların yaşamı acı verici bulduklarını; dünyan in bir anlamsızlık içinde olduğunu düşündüklerini ve ölüm hakikatinin bilincinde oldukları görülür. Tragedyanın Doğuşu'nda Silenos'a kral, insanlar için en iyi ve en mükemmel şeyin ne olduğunu sorar. Silenos şu cevab 1 verir: "Duymamanın senin için en hayırlısı olduğu şeyi söylemeye niye zorlarsın beni? En iyi şey senin için tamamen ulaşılmazdır: doğmamış olmak, var olmamak, hiç olmak. En iyi ikinci şey ise senin içindir - en kısa zamanda ölmek" (Nietzsche, 2016: 57). Bu insanlar, yaşamın tüm bu acı veren taraflarının farkında olmalarına rağmen, yine de dünya yaşamını sonuna kadar olumlarlar ve dahası bu yaşamı haklı çıkarmanın yollarını ararlar. İlkin hiçlikten ibaret görülen ve olumsuzladıkları dünya yaşamını, sonrasında Olympos tanrıları aracılığıyla bir anlama dönüştürürler. İnsanlar, bu güçlü ve ölümsüz tanrılarla birlikte, kendi sonlu ve acılı varoluşlarını haklı çıkarmayı başarırlar. Nietzsche, Tragedya'nın Doğuşu'nda bununla il gili şuna değinir: “Böylesi tanrıların parlak güneşi altındaki varoluş, ulaşılmaya değer bir varoluş olarak duyumsanır ve Homeros'un insanlarının asıl sancısı bu varoluştan ayrılmaya ilişkindir" (2016: 37). Böylece insanlar, yaşamı tüm olumlu ve olumsuz taraflarıyla kabul ederek, kendi trajik varoluşlarını tanrılara yansitırlar.

Antik Yunan tragedya kahramanları göz önüne alındığında, bu kahramanların, yaşamı sonuna kadar olumladıkları görülür. Kahramanlar, yazgılarını her ne olursa olsun kabullenirler. Fakat bu kabullenme, edilgin bir anlama denk gelmemektedir. Aksine yazgılarını kabul ederek ne yaşarlarsa yaşasınlar, yaptıkları eylemlerden pişmanlık duymadıklarını veya vicdan azabı çekmediklerini gösterirler. Bu yazgısal kabullenme boyun eğme anlamında değil; eylemlerin, yazgının bir zorunluluğu olarak kabul edilmesinden dolayıdır. Yaşamı bir bütün olarak kabul ederler ve başlarına gelenlerin tanrıların istenci doğrultusunda olduğunu düşünürler. Nietzsche, tragedyalarla ilgili şuna değinir: "Yaşamın, şeylerin temelinde, görünüşlerin tüm değişimine karşın sarsılmaz derecede güçlü ve zevkli olduğu yolundaki metafizik avuntu burada değindiğim gibi, her gerçek tragedya bu avuntuyla gönderir bizi evimize" (2016: 37). Böylelikle dünyayı, içindeki yaşadıkları düzenin 
getirilerine göre değil, yaşanması gereken ne varsa, ona ket vurmadan tüm arzuların, acıların, mutlulukların veya hüzünlerin kabul edilmesiyle bir bütün olarak yaşarlar. Bunu gerçekleştirebilmenin yollarından biri, yaşamlarındaki en büyük hakikatlerden birine, ölüme, meydan okumakla ilgilidir. Ölümden korkmak yerine, bu gerçeği kabul ederler. Böylece ölüm karşısında edilgin olan benliklerini ona meydan okuyarak etkin kılarlar.

$\mathrm{Bu}$ durumun örneklerinden birine Antigone'nin (Sophokles, 2018) hikâyesinde rastlanır. Oidipus'un kızı Antigone'nin iki kardeşi iktidarı ele geçirmek için yaptıkları mücadele sırasında ölürler. Yeni Kral olan Kreon'un emri üzerine, kardeşlerden Eteocles kahraman kabul edilip şerefli bir törenle gömülecekken, diğer kardeş olan Polyneikes vatan haini kabul edilip gömülmesine bile izin verilmez. Buna cüret edecek kişi ise ölüm ile cezalandırılacaktır. Kralın sözüne karşı gelerek bu durumu kabul etmeyen tek kişi ise Antigone olur. Ölüm ile cezalandırılacağını bildiği halde Polyneikes'in gömülmesini sağlar. Bunun üzerine diri diri gömülme cezasına çaptırılan Antigone, yaptığı suçun bedelinin farkındadır. Başkalarının onu cezalandırması yerine, kendi cezasını kendi verir. Gerçekleştirdiği eyleminin soncundan kaçmaz ve yazgısını kabul eder. Ölümden kaçmak veya affedilmek için bir çaba içine girmez. Eyleminin arkasında durarak yaşamını da ölümü de olumlar. Sisifos'un tanrılar tarafından cezalandırılışında da benzerlikler görülür. Sisifos Tanrılar tarafından bir kayayı en tepeye kadar taşımaya mahkûm edilir. Burada trajik olansa kayanın her seferinde başlanılan noktaya geri düşmesidir. Sisifos her seferinde kayayı yeniden taşımak zorunda kalır. Tam anlamıyla bir kısır döngünün içine mahkûm edilir. Camus, bu durumu şu sözlerle ifade eder: "Tanrılar, yararsız ve umutsuz çabadan daha korkunç bir ceza olmadığını düşünmüş olmalıydılar" (2013: 137). Fakat Sisifos acı verici görünen bu ceza karşısında hiç de çaresiz görünmez. Aksine tanrılara meydan okur ve eylemlerini kabul ederek cezasını çekmeye razı olduğunu gösterir: “Sisifos, bir kahramandır artık. Bu boyun eğme değil, başkaldırıdır. Çünkü tanrılar, sonsuz bir işkence cezasıyla elinden tüm ümidini alarak ona kötülük yapmak istemişler, ümidini kaybeden Sisifos ise, bu kaderiyle yüzleşerek ve uyanarak kendi kurtuluşunu yaratmıştır (...)" (Camus, 2013: 142). Çünkü Sisifos bilir ki yaptıklarının bir bedeli vardır ve bu, yazgısının bir getirisi olarak çekmesi gereken bir cezadır. O da tıpkı diğer tragedya kahramanları gibi yazgısına itiraz etmez. Yaşamı, hatalarını ve ölümü kabul eder.

Bu tragedyalar aracılığıyla, varoluşu değerli kılmanın yolunun, kişinin hem dünyadaki sınırların ve gücün farkında olmasıyla hem de bu sınırları aşmanın bir yolunu bulmasıyla ilişkili olduğunu görülür. Kişi, yaşamda ona sunulan sınırları, kuralların farkındadır. Fakat kendi istekleri, kuralları ve inanmak istediği değerleri de vardır. Kişi yaşamın bu iki zıt yanında, trajik bir varoluşun içine hapsolur. İnsan ancak bu trajik varoluşun içinde kendini aşmanın bir yolunu bulabilir. Kişi gerekirse bir hiç olur, yalnız kalır ya da ıstırap çeker; fakat bunun karşılığında kendi olmayı, yaşamı ve ölümü olumlamayı başarabilir. Nietzsche, bu trajik varoluşu Apollon ve Dionysos Tanrılarının karşıtlığıyla açıklamaya çalışır. Bunlardan ilki olan Apollon, bilinen anlamıyla güneş ve ışık tanrısıdır. Apollon' da ölçü ve denge vardır. Sınırları, uyumu, biçimi temsil eder. Apollon, insanı olgusal dünyanın ve bilincin sınırları içinde dolaştırır. Bu da insanların, kendilerini aşmalarının önünde bir engeldir. Nietzsche, Apollon için şuna değinir: "Kendini bil” ve “Ölçüyü kaçırma!" istemi, estetik güzellik 
zorunluluğuyla at başı gider; kendini yüceltmek ve ölçüyü aşmak, Apolloncu olmayan evrenin asıl düşman daymonlarıdır (...)" (Nietzsche, 2016: 26). Apollon, kişiye, kendi 1şığını gösterir ve bu ışığı aşmasını istemez. Böylece, acılar, hüzünler, mutluluklar karanlıkta kalır. Apollon, aslında insana, acı çekme, sorgulama; yaşa ve öl der. Bu durum kişiyi kendi doğasına karşı yabancılaştırır. İnsan, dünyayı kendi perspektifinden değil; içine doğduğu düzenin içinden bakar. Bireyin kendi dürtüleri, istekleri arka plana atılır, diğer herkes gibi yaşaması gerektiğine inandırılır.

Dionysos ise en yaygın bilinen anlamıyla şarap tanrısıdır. Aynı zamanda coşkuyu, zevki, çılgınlığı, enerjiyi de temsil eder. Apollon'daki dengeli ve sınırlı evren Dionysos ile yıkılır. Kişi, ancak Dionysos ile kendini aşarak, varoluşunu haklı çıkarabilir. Nietzsche, Dionysos ile ilgili şunlara değinir: “(...) insandan doğaüstü bir şey tınlamaktadır: tanrı olarak duyumsar kendini, şimdi kendisi de düşünde tanrıların değiştiğini gördüğü gibi, kendinden geçmiş ve yücelmiş bir biçimde değişmektedir" (Nietzsche, 2016: 20). Burada insan, kendi bilincine vararak aslında doğasının da farkına varır. Apollon'da doğaya karşı olan yabancılaşma, Dionysos ile birlikte kaybolur. Çünkü çevresini tanıyıp onu içselleştiren insan, ancak o zaman doğaya hâkim olabilir: "Dionysos'un büyüsüyle yalnızca insanla insan arasındaki bağ yeniden kurulmuş olmaz. Yabancılaşmış, düşman ya da boyunduruk altına alınmış doğa da kaybolmuş oğluyla, insanla barışma şenliğini kutlar yeniden (Nietzsche, 2016: 19). Dionysos'ta ölüme doğrudan bir övgü yoktur. Fakat dolaylı yoldan bu anlamı çıkarmak mümkündür. Çünkü Dionysos, yaşamı bütün yönleriyle kabul eder. Acılar ve hüzünler de yaşamın bir parçasıdır. Yaşam ve ölüm bütünüyle kabul edilir.

Trajik insan olarak kabul ettiğimiz kavram bu iki tanrıla anlam kazanır. İnsan, Apolloncu sınırların farkında olduğunda ve bunu Dionysosçu bir coşkuyla aşmaya çalıştığında, olgusal dünyanın içinde yer alan, bir gün yokluğa karışacak olan etmenler kişiyi yıkıma uğratmaz; aksine kişi bu geçiciliğin farkına vararak, yaşamını bulunduğu yer ve zaman içinde anlamlı kılmanın bir yolunu arar. "(..) ancak trajik kavrayış, verili durumu dönüştürme, en umutsuz koşullar altındayken bile yaşam istencini dişsallaştıran bir eyleme yönelik umut barındırma gücüne sahiptir." (Çağlıyan, 2017) İnsan, bunu yaparken de diğerlerinin gittiği yoldan değil; kendi inandığı ve istediği yoldan giderek kendini gerçekleştirir. Yaşamın tüm anlamsızlığı, kişinin kendi içinde bir anlam kazanır.

\section{Köle-Efendi Diyalektiği'nde Ölüme Meydan Okumanın Önemi}

İnsanın sonsuzluk arayışı ve buna ulaşabilmek için ölümden korkuyor oluşu Hegel'in felsefesinde bambaşka bir anlam kazanır. İnsanın sonsuzluğa ulaşabilmesi için ölümün gerçekleşmesi gereklidir: "İnsan, sonluluğunun ve dolayısıyla ölümünün bilincine vararak kendisinin bilincini edinebilir ancak. Çünkü İnsan, sonludur ve ölümlüdür" (Kojève, 2001: 134). Aslında ulaşılmaya çalışılan tam da insanın kaçmakta olduğu sonlu varlığının içinde gizlidir. İnsanın sonlu görünen varlığı bu sonsuzluğunun farkına varılmasını engeller. Bu durumda insanın kendini aşabilmesinin önkoşullarından biri ölümüdür. Hegel'in, EfendiKöle diyalektiği de bunun üzerine kuruludur. 
Varlık ilk önce kendini başkasından, ben olmayandan ayırır. Bu yolla açı̆̆a vurulan bilinci, başkaları tarafından da bilinip tanınmak ister. İnsan bu şekilde, özgür bir birey olarak yaşayabilir. Çünkü Hegel'e göre: "doyum, insan oluşturucu ve insansal bilinip-tanınma isteğinin; insanın, kendi tarihsel ve özgür bireyselliğine ya da kişiliğine, bütün öteki insanların mutlak bir değer atfettiğini görme isteğinin doyuma ulaşmasından başka şey değildir" (Kojève, 2001:138). Bunun gerçekleşebilmesi için en az iki farklı bilincin var olması gereklidir. Bilinip tanınmanın önkoşulu ölüme meydan okuyabilmektir. Bu meydan okumanın sonucunda bilinçler farklı şekillerde biçimlenir. Ortaya koyulan ölüm kalım savaşında yaşamını hiçe sayarak ölmekten korkmayan kişi, efendi olurken; ölümden korkan ve olgusal dünyadan kopamayan kişi ise köle konumuna gelir. Aslında, meydan okumanın en başından beri bilinçler birbirlerini öldürme isteği üzerine hareket etmez. Çünkü, taraflardan biri karşısındakini öldürecek olursa, onu bilip tanıyacak kimse kalmaz. Bu durumda birey tanınma amacına ulaşamaz. Bu yüzdendir ki kişi girdiği mücadelede karşısındakini öldürmeyi değil, onu yenmeyi amaçlar: "Başlangıçta başkası tarafından gerçekten biliniptanınmadığı sürece, onun eyleminin amacı bir başkasıdır; insansal değeri ve gerçekliği, bu başkasına dayanır, hayatının anlamı bu başkasında yoğunlaşmıştır" (Kojève, 2001: 90). Böylelikle ölümü pahasına girdiği mücadeleyi kazanan efendi, karşısındaki kişinin canını bağışlayarak ona üstünlük kurar. Onu kendine bağımlı hale getirerek kölesi yapar. Efendi böylelikle özgür bir birey olarak yaşar.

Hayatını bilerek ve isteyerek tehlikeye atan efendi karşısında köle, edilgin bir yaşama mahkûm olur. Köle, dünyevi olanla yetinmeyi, somut olana bağlı kalmayı tercih eder. Efendinin boyunduruğunda yaşıyor olmak, dünyadan kopmaktan daha az acı verici görünür: “O, bir başkası tarafından kendisine bağışlanan hayatı kabullenmiştir. Dolayısıyla, o başkasına bağımlıdır. Köleliği (kulluğu), ölüme tercih etmiştir ve bundan ötürü, hayatta kalarak köle olarak yaşar" (Kojève, 2001: 94). Köle tam olarak bilincine varamamış ve kendini aşamamış olsa da özce insandır. Ancak bilincin tam olarak doyuma ulaşabilmesi için iki tarafın da birbirini tanıyıp bilmesi gerekir. "Yaşamını hiç tehlikeye sokmamış birey hiç kuşkusuz kişi olarak tanınabilir; ama bağımsız bir öz bilinç olarak tanınmışlığın gerçekliğine erişmiş değildir" (Hegel, 2011: 125). Köle, efendiye karşı yenildiği ve onu kendisinden üstün tuttuğu için efendiyi tanır; fakat efendi, köle ile kendini eşit görmez ve onu tanımaz: "Köle, ancak gizil olarak insansaldır; oysa Efendinin insansallığı, somut olarak bilinip-tanınmış olduğu için nesnel olarak gerçektir" (Kojève, 2011: 164). Böylece köle, efendi tarafından bilinip tanınmadan; fakat efendiyi tanıyarak ona emek gücüyle itaat eder. Bunun başlıca nedeni, kölenin efendiden (ölmekten) korkuyor oluşudur. Fakat efendi köleyi kendine özce eşit bir insan olarak görmediğinden köle tarafından tanınmış olmayı da aslında kabul etmez. Köle onun için hala öz bilincini ortaya koyamayan biridir. Kazanılan bu mücadeleden sonra, köle çalışıp doğayı dönüşüme uğratırken, efendi kendi içinde bir çıkmaza girer. Efendi dünyadadır, ama ona hâkim değildir; sadece onun bir parçasıdır. Efendi doğayı köle aracılığıyla tanır. Bu yüzdendir ki efendi kendisini dünyada aşamaz ya da ona hâkim olamaz. Demek ki "efendi kendisini verilmiş dünyanın üstüne yükseltebilecek özgürlüğe, yaşadığı sürece ulaşamaz" (Kojève, 2001: 99). Bu yüzden efendi kendini dünyada tam olarak aşamaz. Köle ise bunun tam aksidir. $\mathrm{O}$, dünyaya ve doğaya hâkimdir. Bu onun kendi tercihi değildir; 
ama köle olarak doğaya hâkim olmak zorunda kalmıştır. Efendisine hizmet için çalışır; doğayı dönüşüme uğratır ve zamanla ona hâkim olmaya başlar. Köle en başından beri ölmekten korktuğu için bu dönüşümü yaratma gücüne -istemeden de olsa- sahip olur. Böylece köle, ilkin sahip olduğu dezavantajı, çalışması ve emeğiyle tersine çevirme imkânı yakalar. Bu köle için uzun ve zorlu bir süreç olsa da zamanla kendi gücünün ve değerinin farkına varır: "Köle, çalışmayla dünyayı dönüşüme uğratarak, kendisini de dönüşüme uğratır ve böylece, başlangıçta, ölüm korkusu yüzünden reddettiği bilinip-tanınma uğruna girişilen özgürleştirici mücadeleye yeniden girişmesini sağlayan yeni ve nesnel koşulları yaratır" (Kojève: 2001: 108).

Ölümü ötelemeye veya onu görmezden gelmeye çabalar. Bunun için kendini birçok uğraş ile -zorunluk olarak da olsa- meşgul eder. Dünyevi rahatlığını ön plana çıkarır. Fakat Hegel'in birçok kez değindiği gibi bireyin hakikatini yani ölümlü yaşamını kabul etmesi önceliktir. Birey ‘ben' kavramını ortaya koyarak, yaşamını etkin bir konuma getirebilmelidir. Köle bilinçten arınmak, dünyayı dönüşüme uğratmak ve efendi olabilmek, ölüm korkusundan kurtulmayı gerekli kılar: "Nihayet, insansal bireyselliğin de ölümle koşullanmış olduğunu söylemeliyiz. Bu sonuç, Hegel ile birlikte, ancak özgür olununca bireysel olunabileceği ve sonlu ya da ölümlü olmadan da özgür olunamayacağı kabul edilerek çıkarsanabilir" (Kojève, 2001: 153). Dolayısıyla Hegel'in düşüncesindeki sonlu olanın sınırı dahi, aslında o sınırın ötesine geçmeye gönderi de bulunduğu için, insanın kendisini aşmasına da bir zemin hazırlar. İnsan kendini yaşadığı süre boyunca aşabilmelidir. İnsandan daha üstün bir güç yoksa ve sadece sonlular arasında geçişin kendisi sonsuzsa, bu demek olur ki insandan daha yüce bir sonsuzluğa da sahip değer koyucu bir güç yoktur.

\section{Albert Camus'de Yaşamın Anlamsızlığına Karşı Bir Başkaldın}

Buraya kadar ele alınan filozofların fikirleri üzerinde durup düşünüldügünde, birtakım sorular ortaya çıkmaktadır. Örneğin, madem dünya gelip geçici, insan ölüme yazgılıysa, o halde yaşamanın bir anlamı var mıdır? İnsan yaşamının bir sınırı varsa ve her şey anlamsızlığa karışma tehlikesi içindeyse, o halde insan neden bunun farkında olup bir şeyler için çabalamaya devam etmelidir? Ölümle birlikte yaşamın anlamsız gelme hissi, Camus'nün tabiriyle saçmayı doğurmaktadır. Fakat burada önemli bir nokta vardır. Camus'ye göre, dünya saçma değildir. Dünyanın kendi içinde bir uyumu ve düzeni vardır. Sorun insanın dünyada olmasıdır. "Ağaçlar arasında bir ağaç, hayvanlar arasında bir kedi olsaydım, bu yaşamın bir anlamı olurdu; çünkü dünyadan bir parça olurdum. Bu dünya olurdum, oysa şimdi tüm yakınlık gereksinimimle onun karşısındayım, öylesine önemsiz olan bu akıl, işte beni tüm evrenin karşıtı yapan bu" (2011: 46). Camus'ye göre dünya ve insan arasında belirlenmiş bir bağ yoktur. İnsanlar olmasa da dünya yine dönmeye, denizler dalgalanmaya, kuşlar uçmaya devam edecektir. Camus bu durumla ilgili şu sözlere değinir: “Gerçekten önemli olan bir tek felsefi sorun vardır o da intihardır; yaşamın yaşamaya değip değmediği konusunda yargiya varmak felsefenin temel sorusuna yanit vermektir" $(2013,21)$. Bu soruya yanit vermek ise göründüğünden çok daha zordur. Çoğu insan için daha en başından ölüm fikri korkutucu ve hüzünlü görünür. Çünkü bir tarafta yaşamın olgusal ve tekdüze tarafı insanı sarmalar. Ona her gün yapmak zorunda olduğu eylemleri hatırlatır. Diğer bir tarafta ise ölüm hakikati vardır. İnsan yaşamının bir gün yokluğa karışacağının bilincindedir. Fakat 
genel olarak insanlar, kendilerini yokluğa karıştıracak bir olgunun peşine düşmektense, olgusal dünyanın izinden gitmeyi, diğer insanlarla birlikte uyum içinde yaşamayı daha kolay bulurlar. Böylece ne ölüm gibi bir olgunun ürperticiliği ne de yaşamın sorgulanması gereken taraflarının bir önemi kalır.

İnsanın dünyaya geldiği andan itibaren yaşadığı her saniye, onu kendi yok oluşuna doğru götüren bir süreçtir. İnsanın belki de birkaç adım ötesinde duran ölüm, ona ara sıra göz kırpar ve kendini hatırlatır. Tam da ölümün kendini hatırlattığı bu anlardan birinde, insan bir an umutsuzluğa ve çaresizliğe kapılarak kendini bir çıkmazın içinde hisseder. Bu aniden ortaya çıkan çaresizlik durumu Camus'nün de değindiği gibi önemli eylemlerin başlangıcını oluşturan temel bir noktadır: “Tüm büyük eylemlerin ve düşüncelerin önemsiz bir başlangıç noktası vardır. Büyük yapıtlar çoğu kez bir sokağın dönemecinde ya da bir lokantanın kapısında doğar" (Camus, 2013: 31). Her şey aynı monotonluk içinde ilerlerken "bir gün neden sorusu yükselir ve her şey bu şaşkınlık kokan bıkkınlık içinde başlar. Bıkkınlık, makinemsi bir yaşamın edimlerinin sonundadır, ama aynı zamanda bilincin devinimini başlatır" (Camus, 2013 , 31). Tam bu noktadan sonra insanın nasıl bir yol çizeceği belli olur. Kişi ya kısır döngüye kaldığ1 yerden devam eder ve yaşamında ne bir bilinçlenmeye ne de bir değişime gitme farkındalığına ulaşır; ya da tam aksine bütün bu anlamsızlığın farkına vararak bilinçli biri haline gelir. Camus'nün saçma (uyumsuz) kavramı da bu durumda kendini gösterir. Kişi yaşamın tüm bu anlamsızlığının içinde uyumsuzluğu görür. Gerçekleştirdiği eylemlerin değerini sorgulamaya başlar. Kaygı, çaresizlik, sıkışmışlık gibi duygular yaşar. Ama en önemlisi, tüm bu olumsuz duyguların içinde bir farkındalığa varılmış olunmasıdır. Artık bu farkındalığa varan uyumsuz hem diğerleriyle birlikte var olmaya hem de içinde yaşadığ kaygılarla baş etmeye çabalar. Zamanla yaşadığı çevreye, insanlara ve belki de kendisine karşı bir yabancılaşma yaşar. Daha önce benimsediği eylemleri veya değerleri şimdi sorgulamak zorundadır. İnsanlar ona bir yabancı gibi görünmeye başlar; çünkü onlar gibi düşünmüyordur, onlar gibi hissetmiyordur. O bambaşkadır ve bambaşka da olmak istemektedir.

$\mathrm{Bu}$ durumda, saçmanın bilincine varmış biri ne yapmalıdır? Camus'ye göre uyumsuzun önünde iki seçenek vardır: "Ya intihar ya da iyileşme" (Camus, 2013: 54). Camus, intiharı olumsuzlar. İntiharı yaşamın saçmalığını ortadan kaldıracak bir çıkış yolu olarak görmez; aksine intihar etmenin saçma olanı kabul etmek ve ona boyun eğmek olduğunu savunur: "İntiharın başkaldırıdan sonra geldiği sanılabilir. Ama yanlış olarak, çünkü intihar başkaldırının mantıksal sonucu değildir. İçerdiği boyun eğiş dolayısıyla, onun tam tersidir" (2013: 68). İntihar, bu hiçliği, saçmalığı yadsıyarak "bunlarla başa çıkamıyorum" demektir: “Yalnızca çabalamaya değmez demektir, kendini öldürmek" (Camus, 2013: 23). Oysa dünya, tüm saçmalığına rağmen yaşanmalıdır. Bu durum Camus için bir diğer önemli kavram olan başkaldırıyı ortaya koyar. Başkaldırı çok önemlidir, çünkü bir bilinçlenmeyi de beraberinde getirir. İnsan başkaldırıyla, "Ben her şeyin farkındayım, hayatın anlamsızlığının, bana dayıtalan kuralların, temeli olmayan eylemlerin bilincimdeyim" der. En önemlisi istemediği değerlere "hayır" demeyi öğrenir. Başkaldırıyla söylenen her hayır kelimesi, bir evetlemeyi de beraberinde getirir. Uyumsuz, istemediği değerlere hayır diyerek kendi içselleştirdiği, onu iyi 
hissettiren değerlere sahip çıkar. Başkaldırı aynı zamanda, yaşamın ve ölümün tümüyle farkında olmaktır. Bu da kişinin yaşadığı "an ve yerde" olması anlamına gelir. Geçmiş veya gelecek yoktur. İnsanın elinde sadece içinde bulunduğu zaman vardır. Eğer ki yaşamda bir anlam ve değer oluşturulacaksa, tam da bulunan yer ve zaman içinde gerçekleştirilmelidir.

Uyumsuz bunu, yaşadığı dünyanın mantığa uymayan değerlerine, yasalarına, geleneklerine birer birer başkaldırarak; onları yok sayarak yapar. Kendi içsel dünyasına dönerek, kendi için neyin iyi ve anlamlı olduğunun farkına vararak, bu değerler üzerine bir yaşam kurar. Camus'nün Sisifos'tan esinlenmesinin nedeni belki de budur. Sisifos tanrılar tarafından verilen cezasını çekerken, hiçbir zaman kayayı yerine koyamayacağını bilir; ama o, bu kısır döngüye rağmen tanrılara başkaldırarak saçmayı olumlar. Onun yaşamı anlamlı kılışı, uyumsuzluğuyla gelen bir başkaldırıdır: "Sisifos'un uyumsuz kahraman olduğu şimdiden anlaşılmıştır: Tutkularıyla olduğu kadar sıkıntısıyla da uyumsuzdur. Tanrıları hor görmesi, ölüme kin duyması, yaşam tutkusu hiçbir şeyi bitirmemeye yönelttiği bu anlatılmaz işkenceye mal olur" (Camus, 2013: 138). Sisifos'un hikâyesini ilginç kılan kısım bunu bilinçli olarak yapıyor olmasıdır. Taşı sürekli aynı yere taşımak zorunda olduğunu bilmektedir. Fakat yine de bundan üzüntü duymaz. Tanrılara başkaldırır. Bu hikâye aslında günümüze de iyi bir gönderme olarak kabul edilebilir. İnsanlar da benzer bir döngünün içindedir. Her gün yaşama tutunabilmek adına aynı eylemleri gerçekleştirmeye, belirli konular hakkında konuşmaya, önceden konulan kurallar etrafında, sorgulamadan yaşama çalışırlar. Fakat günümüz insanlarının Sisifos'tan farkı, bunları bilinçsizce ve adeta robotlaşmış bir şekilde yapıyor oluşlarıdır. İnsanların, bilinçsizce sürdürdüğü bu eylemler, Sisifos'ta olduğu gibi kahramanca veya yazgısal bir kabullenmenin parçası değildir. Aynı zamanda günümüzde gerçekleştirilen çoğu eylem, insanın ölüme yönelik bilincini köreltmeye ve onu unutturmaya yöneliktir. Ölümün varlığını yok saymaya başlayan insan için, bilinçten çok bilinçsizlik hali baş göstermektedir.

Camus'nün Caligula (2015) adlı kitabında da bu düşüncelerin izlerine rastlanır. Camus'nün Caligula adlı oyunu yazmasında, tarihsel bir kahraman olan Roma İmparatoru ilham kaynağı olmuştur. Caligula'nın hikâyesini trajik yapan ölümlü olduğunu bilmesine karşın, ölümsüzlük arayışı içinde olmasıdır. Sevgilisi Drusilla'nın ansızın ölmesi üzerine yaşam ve ölüm üzerinde düşünmeye başlayan kahraman, ölüme yazgılı olan insanın mutlu olmasının mümkün olup olamadığını sorgular. Dünyanın anlamsızlığı karşısında bir çıkış yolu arayan Caligula, içinde bulunduğu yaşamı dayanılmaz bulur. Caligula, "İnsanlar ölür ve onlar mutlu değildir" yargısına varır. (Camus, 2015: 13). Aslında Caligula'yı dehşete düşüren durum, sevgilisinin ölmesi değil; kendisinin de bir gün bu şekilde öleceğinin bilincine varmasıdır. Bundan dolayı, dünyada olmayan bir şeyin peşine düşerek, yaşamını anlamlandırabileceğine inanır. Böylece yaşamını ölümsüzlüğün olduğu başka bir dünya bulmaya adar. Sonuç olarak, ölümsüzlüğü de bulamayacağını anlayan Caligula, kendisini öldürmeye gelen senatörlere karşı koymaz: “Hiçbir insanın kendini tek başına kurtaramayacağını ve hiçbir insanın insanlara karşı yürüyerek özgür olamayacağını öğrendiği zaman, Caligula ölüme boyun eğer" (Cruickshank, 1965: 257). 
Camus, insanlara ölümün yaşamı etkin kılan en önemli olgulardan biri olduğunu hatırlatır. Belki yaşam saçmadır ve yaşamdan bir anlam çıkarmak mümkün değildir; fakat insan ancak bunun bilincine vararak, yaşamı olumlayabilir. Bunu başarmak isteyen insanlar, saçmadan kaçmadan onunla yaşamanın bir yolunu bulmalıdır.

\section{Shakespeare'in Yapıtları Bağlamında Ölüm Konusunun Ele Alınışı}

Shakespeare'in, kralları ve soyluları ele aldığı eserleri, çalışmanın ana problemini çözüme götürebilmek adına önemli bir yere sahiptir. Çünkü özellikle krallar, dünyada neredeyse tanrısal diyebileceğimiz bir güce sahiptirler. Arzu ettiklerine kavuşmaları, çoğu insana göre çok daha kolaydır. Sıradan bir insanın gerçekleştirebileceği eylemler ile bir kralın gerçekleştirebilecekleri aynı değildir. Bu yüzden Shakespeare'in kral ve soyluları ele aldığ oyunları, insan potansiyelinin sınırlarını görebilmek adına önemlidir.

Shakespeare'in tragedyalarında özellikle var olmak nedir? Yaşamak için var olmak yeterli midir? İnsan yaşam ve ölüm uğruna neleri göze alabilir? İnsanın dünyada yapabileceklerinin sınırı nedir? gibi birçok soruya yanıt aranır. İnsanın kendi benliğini var edebilmesinin, kısa sayılacak dünya yaşantısını değerli kılabilmesinin yollarını, Shakespeare, birçok farklı tragedya aracılığıyla sunar. Örneğin, Othello (2019a) sevdiği kadınla; Macbeth (2018) krallık ve kehanetlerle; Hamlet (2019b) yaşamın anlamsızlığıyla; Kral Lear (2019c) kızları ve yaşlılığıyla; Sezar (2019d) gücüyle ve dostlarıyla; Lady Macbeth, ihtiraslarıyla sınanır. Bu sınanmalar aracılığıyla, hayatın farklı açılardan sorgulandığı görülür. Bu sorgulamalar açık bir anlatımla yapılmaz ve hikayelerin alt metinlerinde sunulur. Shakespeare'in karakterlerine, Nietzsche'nin düşünce sistemiyle baktığımızda, karakterlerin genellikle Apolloncu olgusal dünyanın içine hapsoldukları ve kendi sınırlarını aşamadıkları görülür. Karakterlerin bazılarında zaman zaman Dionysosçu bir coşku ve delilik görülse de, bunların bir bilinçle veya tercihle yapılmadığı, adeta hayvansal bir içgüdüyle ortaya koyulduğu görülür. Shakespeare' in karakterleri, duyguları yoğun bir şekilde yaşarlar. Günlük hayatta birçok insanın yaşadığı durumları, onlar gündelik olmaktan çıkarır ve bunları en şiddetli, en acımasız ve en doyumsuz şekilde ortaya koyarlar. Örneğin Othello âşık olduğu ve güvendiği karısını başka insanların sözlerine inanarak öldürür, en sevdiği insanı öldürecek kadar ileriye gitmesi, başkaları tarafından küçük görülmemek için tüm yaşamını hiçe sayabileceğinin bir göstergesi olur. Hamlet ise, yaşamı anlamsız bulur ama aynı zamanda ölmekten de korkar. Bu yüzden ne yaşamı ne de ölümünü haklı çıkarmayı başarabilir. Anlamsız eylemler etrafından kendini ölüme kadar sürükler. Brutus, kazanabileceği bir unvan için, dostu Sezar'ın arkasından entrikalar çevirmekten ve onu öldüren son darbeyi vurmaktan çekinmez. Bu yüzden Shakespeare'in oyunlarında, insanların yüce olarak gördüğü mevki, aşk, ün, zenginlik için neleri göze alabileceğinin trajik örneklerine sıklıkla rastlanır. Örneğin, Kral Lear'daki, Edmund karakteri, büyük bir servete ulaşabilmek için babasını ve kardeşini düşünmeden yok etmeye hazırdır. Ya da Lady Macbeth, kendi kişisel arzularını doyurabilmek için cinayet işlemekten, diğer insanların hayatlarını hiçe saymaktan çekinmez. Desdemona aşkı ve gururu için kendini tüketir.

Fakat Shakespeare'in karakterleri, Yunan tragedyalarının aksine, Nietzsche'nin değindiği yaşamın değerini ortaya koyabilecek, yaşamı haklı çıkarabilecek "trajik insan" 
olmaktan oldukça uzaktırlar. Yaşamın acı veren, ıstıraplı tarafları göz ardı ederler. Yazgısını onaylamayan, yaşamın hakiki tarafını aramaktan kaçan karakterlerdir. En güçlü görünen karakterlerde bile bu durum söz konusudur. Örneğin, Macbeth, Banqou'yu,Lady Macbeth, Kral Duncan'1,Brutus, Sezar'1, Othello, Desdemona'yı, ölüme mahkûm ettikten sonra büyük pişmanlık duyar. Kral Lear kızlarına güvendiği için pişmandır; Hamlet ise anlamsızlık içinde geçen yılların pişmanlığını yaşar. Hiçbiri, yaptıkları eylemlerin arkasında durmazlar. Aksine bunların kendi hatalarını olduğunu kabul etmek yerine, başkalarının hatası olduğuna kendilerini inandırmak isterler. Çoğu zamanda bu doğrudur, çünkü karakterler başkalarının yönlendirmesine açıktırlar. Bu, Shakespeare' in sıklıkla başvurduğu bir yöntemdir. Örneğin, Macbeth'in hırslarını tetikleyen dış güç Lady Macbeth ve cadılar, Kral Lear'da Edmund, Othello' da ise Iago karakterleridir. Hamlet'i eyleme geçiren dış güç ise bir hayalet olur. Tüm bu karakterlerin, kendi değerlerini belirlemekten uzak ve zayıf oldukları da böylece ortaya koyulur.

Sonuç olarak da ölüm bilincine varamayan karakterlerin neredeyse hepsi mutsuz bir şekilde yaşamlarının sonuna gelirler. Uğruna mücadele ettikleri ne varsa ölüm ile birlikte yok sayılarak değersizleşir. Ne kibirli Kral Lear ve kızları ne de miras için ailesini yok etmeye hazır olan Edmund; ne Othello ne de Sezar yaşarken anlamlı bir değer yaratmayı başarabilir. Burada değinilen tragedyalardaki neredeyse bütün karakterler, trajik bir yaşam sonrasında, ölümün kaçınılmazlığıyla karşılaşırlar. Shakespeare'in farklı eserlerinde ortak nokta, karakterlerin ölümü göz ardı ettiklerinde, yaşamın geçiciliğini de unutarak yaşamlarında edilgin bir konuma sürüklenmeleridir. Böylece yaşamlarında bir anlamsızlık oluşur ve bu anlamsızlık bir türlü aşılamaz. Her bir karakter, yaşamın sorgulanması gereken taraflarını yaşamla birlikte gelen hazların, arzuların, hırsların arkasına gizleyerek hayata kalmaya çalışır. Shakespeare'in, eserlerindeki karakterler de ölümü kendilerinden uzaklaştırmaya çalıştıkları ve kendilerini salt dünya nimetlerine adadıkları için yaşamlarını ve ölümlerini haklı çıkarmayı başaramazlar. Yaşamlarında kalıcı bir anlam oluşturmayı başaramadan yitip gitmeye yazgılı olurlar.

Macbeth tragedyası (Shakespeare, 2018) ise, bu çalışma için, farklı bir öneme sahiptir. Çünkü Shakespeare'in diğer tüm eserlerinin içerisinde Macbeth, dünyada insanın ulaşabileceği sınırın en uç örneklerden birini sunar. Macbeth, cadılar tarafından yenilmezliğe/ölümsüzlüğe işaret eden bir kehanet alır. Böylece, insanların yüzyıllardır düşlerini süsleyen ölümsüzlük arzusunun, bir kral üzerinde nasıl bir etki yarattığını, eylemlerini, bilincini hangi yönde etkilediğini görebiliriz. Macbeth üzerinden, insanoğlunun ölüm bilincini geri attığında nasıl bir gelişim gösterdiğinin bir portresini ortaya koymak mümkün olur. Macbeth'in hikayesini trajik yapan en önemli etmenlerden biri, başkalarının yarattığ1 değerler üzerinden kurguladığı yaşantısının ve kimliğinin ona bir türlü doyum sağlamamasıdır. Bundan dolayı ne var oluşunu ne de yazgısını kabul etmeyi başaramaz. Bir kral olsa da maddiyata indirgediği yaşamında bir köle gibidir.

Macbeth'in hikayesini böylesine trajik yapan taraf nedir? Yazgısını onaylamaması mı? Hırsları uğruna tüm benliğini bir hiçliğe doğru sürüklemesi mi? Yoksa yaşamında bir anlam yaratmayı başaramadan ölüm ile karşı karşıya gelmesi midir? Belki de bunlardan hepsi ve daha fazlasıdır. Shakespeare, hikâyenin daha ilk başından itibaren Macbeth'i birçok sınava 
tabi tutar ve onun seçimlerini bir şekilde insanoğlunun doğasıyla bağlantılı bir hale getirir. Macbeth'in yaşadıkları, günlük hayatın içinde karşılaşılan duygularla benzerlik gösterse bile bundan çok daha ötesini ortaya koyar. İnsanın en uç noktalarını, en gizli hislerini, en tehlikeli arzularını saklandığı yerden çıkartır. Macbeth'in zaafları ve seçimleri yazgısıyla karşı karşıya geldiğinde, tüm benliğini ve yaşamını değiştirecek bir dönüşüme uğrar. Hikâyede anahtar bir role sahip olan cadıların anlamı da önemlidir. Cadılar, hikâyede insanın zaaflarını, arzularını, hırslarını ortaya çıkartan kışkırtıcı bir güç olarak kullanılır. İnsanın çok daha üstünde konumlanırlar. İnsani hırslardan ve arzulardan arınmış olan varlıklardır. İnsanlar ile uğraşıyor olmaları, kendilerini yüce ve üstün gören insanoğluna ne kadar güçsüz olduklarını hatırlatırlar. Adeta insanlarla alay ederler. Verdikleri kehanetlerle onların yaşamlarını alt üst ederler. Karakterlerin, gelip geçici nesneler uğruna ellerini kana bulamaları, birbirleriyle savaşmaları, hain planlar kurmaları cadıları haklı çıkartır. Hikâyenin daha en başından soylu, erdemli ve iyi bir komutan olarak tasvir edilen Macbeth'in cadıların kehanetleri sonrasında, arzularına yenilerek büyük bir dönüşüm geçirmesi de bunun en büyük kanıtı olur. Öyle ki erdemleriyle yaşayan Macbeth, tek bir cümleyle bir caniye dönüşmeye hazırdır. Bu durum insan doğası hakkında da birçok şey söyler. Kimsenin doğrudan iyi veya kötü olmadığının bir göstergesi olur.

Macbeth tragedyasındaki temel noktanın, sonluluk göz ardı edildiğinde, insanın geçiciliğini unutarak kendini maddi olanlarla var etmeye çalışması; fakat asla doyuma ulaşamaması olduğu görülür. Bu yüzden Macbeth her ulaştığı hedefi sonrasında daha fazlasını arzular. İlk önce bir beylik, sonra krallık, sonra düşmanlarının soyunu yok etmek; kendi soyunu devam ettirmek ve krallığa hep hükmetmek gibi isteklerin sonu gelmez. Bir doyuma ulaşamaması, kendi istemiyle bir anlam yaratamamasının bir yansımasıdır. Başkalarının onayını ve saygısını kazanmak için çabaladığı hiçbir şey bireysel mutluluğa erişmesini sağlamaz. Aynı şekilde Lady Macbeth de yaptığı eylemlerin sonuçlarına katlanmayı başaramaz. Delirmeye başlar. Çünkü o da yazgısıyla barışık değildir. Güçlü görünümünün altında zayıf bir karakter yatar. Hedeflediği, arzuladığ1 nesnelerin kölesine dönüşür. Bu da yaşamının anlamsız bir şekle bürünmesine neden olur. Uğruna cinayetler işlettiği tahtın, bir önemi olmadığı, tahtı önemli gösterenin tutkuları olduğunu anlar. Çünkü insan yazgısını kabul edip onu olumlamadığı sürece benliklerini aşamazlar. İnsan, kendisini toplum değerlerinin uyarınca kalıplaşmış arzuların içinde sıkıştırdığında özünü de kaybeder. Fakat tüm bunları fark edemeyecek kadar da körleşmişlerdir. Yaşamını öldükten sonra değeri olamayacak ya da yaşarken de doyuma ulaştırmayacak maddi varlıklara adaması, ortaya kalıcı bir anlam bırakmasının önüne geçer. Yaşamının bir hiçlikle son bulmasına neden olur. Böylece Macbeth aracılığıyla, insanın yüzyıllardır aradığı ölümsüzlük isteğinin, ona bir yarar sağlamayacağının, yaşamın ölümle birlikte bir anlam kazanacağının; fakat bu anlamında ancak ölüm bilincine sahip olarak kazanılabileceğinin bir anlatısı aktarılır.

\section{Ölüm Olgusunun Sinema Aracılığıyla Ortaya Koyulması}

\section{Kanlı Taht (Kumonosu-Jō, Yön. Akıra Kurosawa, 1957)}

Akira Kurosawa'nın Macbeth'i doğrudan uyarladığını söylemek hatalı ve eksik olur. Hikâyenin genel hatlarında benzerlikler bulunsa da birçok karakter ve sahnenin çıkarıldığı, 
Shakespeare'in şiirsel diline ve diyaloglarına bağlı kalınmadığı ve karakterlerin isimlerinin de değiştirildiği görülür. Kurosawa'nın filminde Macbeth, bir samuray olan Washizu karakteridir. Film İskoçya da değil, Japonya' da geçer. Kurosawa uyarlamayla ilgili şunlara değinir: "Zayıfın güçlü için bir ava dönüştüğü bir çağda yaşayan insanların görüntüleri bir hayli yoğun. İnsanlar büyük bir yoğunlukla tasvir ediliyor. Bu anlamda, Macbeth'te benim diğer bütün eserlerimde ortak olan bir yön olduğunu düşündüm" (Akt: Price, 2013:132).

Kurosawa, Shakespeare'in aksine ölümün varlığını ve kesinliğini metin aralarına gizlemez. Daha ilk sahnelerden filmin temasını bunun üzerine kurar. Ruhun, Washizu ve Miki'ye söylediği sözler, insanların bildiği fakat günlük yaşamın içinde arka plana attığ1 ölümün bir hatırlatması olur. Ruh, Washizu ve Miki aracılığıyla insanlara, yaşamın hirslar ve salt maddiyat için harcanmaya değmeyecek kadar kısa olduğunu ve insanın her anının ölüme doğru giden bir yolculuk olduğunu anlatır. Kurosawa, olayları, içinde çıkılamayan bir döngü olarak sunar. Filmin başlangıç ve bitiş sahnesi aynıdır. Bir koronun söylediği şarkıyla başlar ve yine aynı şarkıyla biter. Şarkı da anlamsal olarak, insanın egoları ve arzularının ölümün önüne geçtiği zaman, benlikte oluşturacak sstırapların bir anlatısıdır. Bir başka döngü de Washizu'dan önceki kralın, bir önceki kralı öldürerek tahta geçmesidir. Sürekli farklı insanların üzerinden, benzer olaylar yaşanır. Böylece bu içinden çıkılamayan döngüsellik, yazgıdan ne yapılırsa yapılsın kaçılamayacağının ve yaşamın bir şekilde benzer durumlar etrafında akıp gittiğinin bir göstergesi olur.

Shakespeare'in cadılarının yerini alan Ruh ile birlikte- hayatın saçmalığı, anlamsızlığı ve insanların gerçekleştirdiği eylemlerin manasız olduğu hatırlatılır. Washizu karakteri, en başta bunu büyük bir istekle dinlese de daha sonra öğreneceği kral olma kehanetiyle, ölümün, yaşamın sorgulanmasının ve hayatın amacının bir önemi kalmaz. Tek önemli olan yakında bir kral olacak olmasıdır. Washizu karakteri, Camus'nün ortaya koyduğu saçmanın bilincine varamaz. Ölümün kati gerçekliğini arka plana atıyor olması, yaşamını kendi içselleştirdiği değerlerden uzak olarak yaşamasına neden olur. Böylece, Washizu için diğer her şey önemsizleşir. Daha sonraki sahnelerle bu anlam pekişir. Bir sahnede, Washizu, hayaletin yanından geçip ormanda ilerlerken, yerde duran yüzlerce insan kafatası ve kemiğe dönüşmüş insan bedenin arasından geçmek zorunda kalır. Evren ona, ölümün kesinliğini hatırlatır. Sonu burada yatan bedenlerden daha ötesi değildir. Fakat karakter için bunların bir önemi yoktur. Ormanın içinde kaybolma sahnesiyle bu anlam pekişir. Düşmanlarını her defasında alt ettikleri, evleri olarak gördükleri ormanın içinde bir sağa bir sola dönüp durmaları, yolu bulamamalarıyla, kendilerine ve çevrelerine yabancılaşmaya başladıklarının bir anlatımı yapılır. Ne yapacaklarını bilmez gibidirler. Salt maddi olana indirgenen yaşam birden anlamsızlaşır. Dakikalarca amaçsız bir döngünün içine hapsolurlar. Tam yanlarında duran kaleyi görememeleri, karakterlerin, kendi varoluşsal varlıklarını görememelerini sembolize eder. Bu durum, Hegel'in insanın ancak, ölümünün bilincine vararak kendisinin bilincini edinebilir, sözlerini hatırlatır. Aynı zamanda Kurosawa'nın filmin içinde kullandığı yağmur, gök gürültüsü gibi kötü hava koşulları sadece karakterlerin ruh hallerini yansıtmakla kalmaz ve eylemlerinin oluşturduğu olumsuz sonuçların da evrene yansıdığını gösterir. Nietzsche'nin değindiği gibi, kendi güçlerini ortaya koyamayarak, başkalarının değerler altında yaşamaları, 
Washizu'nun kendi doğasını kabul edememesiyle somutlaşır. Bu sahnelere yansır ve karakterlerin yabancılaşması ve yalnızlığı doğayı da yalnızlaştırır. Hayvanların huysuzlanması, atların yerlerinde duramamaları da bu durumu onaylar.

Bu yabancılaşmanın ardında Apollon ve Dionysos'un izlerine rastlamak mümkündür. Özellikle Washizu ve Lady Asaji karakterlerinde Dionysosçu esrimeler görülse de kendilerini olgusal dünyanın içinde aramaktan da kurtulamazlar. Bu anlamda Apolloncu bir alanın içinde oldukları, kendi sınırlarını maddi varlıkların, daha en başından onlara ulaşmaları söylenen sınırın, yüceliğin izinde oldukları görülür. Peşinde oldukları değerler, dünyada yüce ve önemli görüldüğü için onlar da çoğu insan gibi bu hedefin peşinden giderler; bu sınırın ötesinde aramaları gereken arzularını, yaşamın anlamını, acıları ve ölümü unuturlar. Bir gün ölmeyecekmişçesine yok olup gidecek birtakım nesneler için varoluşlarını tüketirler. Aynı zamanda Apolloncu etkide olduklarını, eylemlerinin arkasında durmamalarından; acıyla ve mutsuzlukla karşılaştıklarında onunla yüzleşmekten kaçmalarından anlaşılır. Karakterler, Nietzsche'nin övgüyle bahsettiği, Antik Yunan tragedya karakterlerinden son derece farklıdırlar. Oradaki karakterler gibi yazgılarını olumlamak, yaşamı tüm olumlu ve olumsuz duygularıyla kabul etmek yerine bundan sürekli kaçmaya çalışırlar. Örneğin Lady Asaji (Lady Macbeth) yardım ettiği cinayetlerden, söylediği sözlerden zamanla büyük bir pişmanlık yaşar ve eylemlerinin sonuçlarını katlanmayı kabul etmez. Washizu ise öldürdüğü insanların hayaletlerini görür; zamanla delirmeye başlar. Sürekli 1stırap içindedir. Bu karakterlerin bu kadar acı çekiyor olmaları ve hiçbir şekilde doyuma ulaşamamaları, yaşamın bir gün son bulacak olduğunun ve başlarına gelen olayların kendilerinden üstün olan bir yazgının uyarınca gerçekleştiğini kabul etmiyor olmasındandır. Karakterler Dionysosçu bir kabullenme içinde olsalardı, yaşamın bu ıstırapları taraflarının bir gün geçip gideceğinin, bunların kendini aşmak için kullanabileceğinin ve anlamlı bir yola girmek için araç olduğunun bilincine varabilirlerdi.

Washizu, kehanet ile birlikte kral olacağını öğrendiğinde ulaşabileceği sınırı da görür. Bu yoldaki aşamaları sırasıyla yaşamak yerine, sonuca hemen varmak ister. Sürekli geleceğe yönelik yaşar. Şu an içinde bulunduğu yere ve zamana değer veremez, yaşayamaz. Ama geçmişteki eylemlerinden mutlu değildir hep pişmanlık içindedir. Gelecekte ise tekrardan bir tatminsizlik yaşar. Yani geçmiş, şimdi ve gelecek doyumsuzluk ve mutsuzluk içinde harmanlanır. Bu durum Camus'nün düşüncelerini haklı çıkarır. Camus, insanın geleceği tasarlamadan, tam da bulunulan anın içinde olunması gerektiğini savunur. Böylece ne geçmiş bir hüzün ne de gelecek bir umutsuzluk yaratır. Aksine insan içinde bulunduğu yerde ve zamanda kaldığı sürece yaşamın tadını varma şansı yakalar. Yaşamın anlamının şimdinin içinde bulmak önem kazanır.

Washizu, ancak yenilmez olmadığını (Dolayısıyla ölümsüz de olmadığını) anlamak zorunda kaldığın da bir anlam arayışı içine girer. Washizu'yu ölüme götüren tarafı da bu olur. Her ne kadar önceden sınırını biliyor olsa da bu sınırda ölümlügüünü görmez. Kibrine, egosuna yenilir ve kendisini ölümsüz ve yenilmez bir güç olarak tasarlar. Evren ise ona daha üstün bir güç olan yazgısını hatırlatır. En büyük değişikliklerden biri, Macbeth ve Washizu'nun ölüm şeklinde olur. Bilindiği gibi Macbeth, kafası kesilerek en büyük düşmanı Macduff tarafından 
öldürülür. Bunun tam aksine Kanlı Taht filminde Macduff karakterinin rolü oldukça azdır ve neredeyse bir önemi yoktur. Washizu, kafası kesilerek değil, onlarca okun üstüne atılmasıyla ölür. Trajik olan kimin tarafından öldügüünün dahi belli olmamasıdır. Buradan iki farklı anlam çıkarılabilir. İlki, Washizu'nun usta bir ok atıcısı olduğu, düşmanlarını bu şekilde öldürdüğü bilinir. Onu oklarla öldürmeleri, Washizu'yu kendi silahıyla vurulmaları anlamına gelir. Bu da dolaylı yoldan gerçekleştirdiği tüm eylemlerinin dönüp dolaşıp onu bulduğu ve ölümünün de bu eylemlerin bir sonucu olduğunu yansitır. Bir diğer anlam ise, düşmanın kimin olup olmadığının önemsizliğidir. Önemli olan Washizu'nun ölüm ile karşı karşıya gelmesidir. Kurosawa, durumu kişiselleştirmeden çıkartır ve yeniden evrensel bir anlatım sunmayı tercih eder. Böylece Washizu'yu öldüren kişi değil, Washizu'nun ölüm karşısındaki çaresizliği, göz ardı ettiği ölüm ile yüz yüze kalması ve ölümden kaçamamış olması önem kazanır.

Sonradan gösterilen sahneler de bu durumu onaylar. Koronun söylediği şarkıyla, Washizu' nun sonluluğunu unutarak, dünyevi olan için tüm yaşamını tüketmesiyle alay edilir. Örümcek ağı kalesi yeni kurbanlarını bekler. Washizu'nun hırsından ve kibrinden doğan açlığı, ona özgü değildir. Ondan sonra geleceklerin de böyle bir döngüye gireceklerinin bir anlatısıdır. Koro, bilge bir şekilde şarkısını söylerken, bu korodakilerin insan mı yoksa doğa üstü bir varlık olup olmadığı dahi belli değildir. Washizu'nun yaşamındaki hakimiyeti kaybetmesine, pişmanlıklarına ve trajik sonuna bakıldığında, bunların en temel nedeninin ölümlü varlığının anlamını kavrayamaması olduğu varsayılabilir. Koronun şarkısı şu şekildedir: "Aldanışın kalesinin ardındaki kalıntılara bak... Artık sadece yok olanların ruhları uğruyor buraya... Bir katliam sahnesi tüketme arzusu asla değişmiyor. Örümcek ağ kalesi burada yatıyor. Şimdi ve sonsuza dek..."

\section{Sonuç}

Konu üzerine detaylı bir araştırma yapıldığında, insanın kendi yaşamına hâkim olması, anlamlı bir yaşam sürdürebilmesi ile ölüm bilinci arasında güçlü bir bağlantı olduğu gözlemlenmektedir. Çünkü ölüm geri plana atıldığında, insanlar yaşamın gelip geçiciliğini unutmaya başlayarak sınırlı yaşantılarını anlamlı bir bütünlüğe dönüştürmekten yoksun olmaktadırlar. Bundan dolayı, ölümün hatırlanması ve en az yaşamın kendisi kadar doğal bir süreç olarak görülmesi, bireylerin kendi kimliklerini oluşturabilmeleri adına önem arz etmektedir. İnsan, ölümü olumlandığı sürece, dünyada edimsel olmayı başarma imkânı yakalayarak; kendi gerçekliğini ve değerlerini bulma/yaratma şansı yakalamaktadır. Çünkü ölüm, en az yaşam kadar gerçektir. Bu da insanın, bu olguyu kabullenmesini, onunla barışmasını ve uyum içerisinde yaşamasını zorunlu hale getirir. Birey nasıl ki yaşama sırt çevirerek etkin bir şekilde yaşayamıyorsa; ölüme sırt çevirdiğinde de aynı şekilde bir eylemsizlik ve anlamsızlık içinde zamanını tüketmeye başlar. Bundan dolayı ölümün varoluş üzerinde nasıl bir güce sahip olduğunu anlamlandırmak önemlidir.

Ölüm, yaşamı geçici kılarken, insanın bir anlam yaratmasını da sağlar. Geçici olan dünya yaşamı, insanın içinde bulunduğu uzam ve zamanı anlamlı kılacağı bir eylem içine girmesini gerektirir. İnsanın sonlu oluşu, onu eyleme geçmek için motive eder. Yaşamın bir sınırı vardır ve insan dünyadan yok olamaya yazgılıdır; fakat tam da bu yüzden insan 
yaşamında asıl güç olmayı başararak, kendi varoluşunu ve ölümünü haklı çıkarmanın bir yolunu aramaya itilir.

Sınırlı varlığını yaşarken ve öldükten sonra da anlamlı kılabilecek bir kalıcılık yakalama şansı yakalar.

\section{Kaynakça} Yayınları

Camus, Albert (2009). Başkaldıran İnsan, çev . Tahsin Yücel, İstanbul: Can

Camus, Albert (2013). Yabancı, çev.Tahsin Yücel, İstanbul: Can Yayınları

Camus, Albert. (2011). Sisifos Söyleni, çev. Tahsin Yücel, İstanbul: Can Yayınlar1

Camus, Albert. (2015). Caligula, çev. Ayberk Erkay, İstanbul: Can Yayınları

Çağlıyan ÇE (2017). Tragedyanın Özündeki Dionysosçu Bilgelik ve Sinemadaki İzleri. Sinefilozofi; 2(3):35-56. ( Uluslararası Hakemli Dergi )

Friedrich, Hegel (2011). Mantık Bilimi, çev.Aziz Yardımlı, İstanbul: İdea Yayınevi

Friedrich, Hegel. (2016). Tinin Görüngübilimi, çev.Aziz Yardımlı, İstanbul: İdea Yayınevi

Friedrich, Nietzsche. (2001). İyinin ve Kötünün Ötesinde, çev. Prof. Dr. Ahmet İnam, İstanbul:

Friedrich, Nietzsche. (2011). Ahlakın Soykütüğü, çev. Zeynep Alangoya, İstanbul: Kabalcı Yayınevi

Friedrich, Nietzsche. (2016). Tragedyanın Doğuşu, çev. Mustafa Tüzel, İstanbul: İthaki Yayınevi Yayınlar1

Gılgamış Destanı, (2016). çev. Sait Maden, İstanbul: İş Bankası Kültür

Kojève, A. (2001). Hegel Felsefesine Giriş, çev. Selahattin Hilav, İstanbul: Yap1 Kredi Yayınları

Malpas, Jeff., Solomon, R. (Ed.) (2017) Ölüm ve Felsefe, çev. Nur Küçük, İstanbul: İthaki Yayınları.

Schopenhauer, A. (2017). Ölüm ve İçsel Doğamızın Yok Edilemezliği ile Olan İlişkisi, çev. Elif Yıldırım, İstanbul: Oda Yayınları

Shakespeare, William (2018). Macbeth, çev. Sabahattin Eyüpoğlu, İstanbul: İş Bankası Kültür Yayınları

Shakespeare, William (2019a). Othello, çev. Özdemir Nutku, İstanbul: İş Bankası Kültür Yayınları 
Shakespeare, William (2019b). Hamlet, çev. Sabahattin Eyüpoğlu, İstanbul: İş Bankası Kültür Yayınları

Shakespeare, William (2019c). Kral Lear, çev. Özdemir Nutku, İstanbul: İş Bankası Kültür Yayınları

Shakespeare, William (2019d). Julius Caesar, çev. Sabahattin Eyüpoğlu, İstanbul: İş Bankası Kültür Yayınları Yayınevi

Sophokles, (2018). Antigone, çev. Ari Çokona, İstanbul: İş Bankası Kültür

Tolstoy, L. (2014). İvan İlyiç̧' in Ölümü, çev. Nihal Yalaza Taluy, İstabul: Can Yayınları

Metinde İncelenen Film:

Kanlı Taht (Kumonosu-jô, yön. Akira Kurosawa 1957) 